\title{
Deteksi Transgen (Glu-1Dx5) pada Populasi Padi (Oryza sativa L.) Putative Transgenik Kultivar Fatmawati
}

\author{
Nono Carsono ${ }^{*}$, Sri Nurlianti ${ }^{2}$, Inez Nur Indrayani ${ }^{3}$, Ade Ismail ${ }^{1}$, \\ Tri Joko Santoso ${ }^{4}$ dan Murdaningsih H Karmana ${ }^{1}$ \\ ${ }^{1 *}$ Fakultas Pertanian Universitas Padjadjaran \\ Jl. Raya Jatinangor Km. 21 Bandung 40600. \\ 2Alumni Fakultas Pertanian; ${ }^{3}$ Mahasiswa Fakultas Pertanian Unpad \\ ${ }^{4}$ Staf Kelti Biologi Molekuler BB Biogen, Jl. Tentara Pelajar 3A Bogor 16111. \\ "Korespondensi: ncarsono@unpad.ac.id
}

\begin{abstract}
Detection of Transgene (Glu-1Dx5) on Population of Putative Transgenic Rice (Oryza sativa L) Cultivar Fatmawati

A Glu-IDx5 gene, a major gene responsible for elasticity and dough functionality of bread wheat, has been successfully transferred to rice cv. Fatmawati by using particle bombardment. This transformation effort aimed to improve rice dough functionality. The promising lines have been obtained, however since self pollination has been occurred for one to two successive generations, it may result in segregating of the transgene in the next generation. To detect Glu-IDx5 gene in transgenic population molecular analysis, such as using Polymerase Chain Reaction (PCR) which amplify abundant of specific DNA sequence (gene) in short time, could be employed. The objective of this experiment was to obtain transgenic rice plants that contain GluIDx5 gene. Genomic DNAs from 149 plants ( $\mathrm{T}_{1}$ generation are 14 plants, $\mathrm{T}_{2}$ generation are 134 plants, one non transgenic plant) have been extracted by Genomic DNA Purification Kit from Fermentas. Plasmid pK+Dx5 (as DNA template for positive control), Taq DNA polymerase (Go Green Taq ${ }^{\circledR}$ Master Mix from Promega) and two specific primers for amplification of coding region of Glu-1Dx5 were applied. Result revealed that putative transgenic rice contained Glu-IDx5 were as follows: $\mathrm{T}_{2}-7$ were 26 plants, $\mathrm{T}_{2}-11: 12$ plants, $\mathrm{T}_{2}-12: 3$ plants, $\mathrm{T}_{2}-40: 3$ plants, and $\mathrm{T}_{2}-45$ were 5 plants. All $\mathrm{T}_{1}$ plant didn't have Glu-1Dx5 gene in their genome. This suggests that Glu-1Dx5 gene has been integrated into their genome and pass from generation to generation.
\end{abstract}

Keyword: PCR, Putative Transgenic Rice, Transgene Detection.

\begin{abstract}
ABSTRAK
Transformasi gen Glu-1Dx5, pengendali utama karakter elastisitas dan daya mengembang adonan dari gandum, telah berhasil ditransfer ke dalam genom tanaman padi kultivar Fatmawati dengan menggunakan penembakan partikel, dengan tujuan untuk memperbaiki kualitas adonan tepung beras. Galur-galur harapan telah diperoleh, tetapi karena telah mengalami penyerbukan sendiri selama 1-2 generasi yang menyebabkan transgen mengalami segregasi, maka diperlukan upaya pendeteksian transgen pada populasi putative transgenik ini. Upaya ini dapat dilakukan, antara lain dengan menggunakan teknik Polymerase Chain Reaction (PCR) yang memungkinkan perbanyakan fragmen DNA yang spesifik (gen) secara cepat dalam jumlah banyak. Percobaan ini bertujuan untuk mendapatkan tanaman padi transgenik yang memiliki gen Glu-1Dx5 pada dua generasi yang sedang bersegregasi. DNA genom dari 149 tanaman padi (generasi T1 sebanyak 14 tanaman, generasi $\mathrm{T}_{2}$ sebanyak 134 tanaman, dan satu tanaman non-transgenik) telah
\end{abstract}


diekstraksi menggunakan Genomic DNA Purification Kit dari Fermentas. Plasmid $p K+D \times 5$ digunakan sebagai positif kontrol, selain itu digunakan juga enzim Taq DNA polymerase dari Go Green $T a q^{\circledast}$ Master Mix (Promega) dan 2 primer spesifik yang mengamplifikasi coding region dari Glu-1Dx5 (2,5 kb). Hasil percobaan menunjukkan, tanaman padi yang memiliki gen Glu-1Dx5 pada generasi $\mathrm{T}_{2}-7$ sebanyak 26 tanaman, $\mathrm{T}_{2}-11: 12$ tanaman, $\mathrm{T}_{2}-12: 3$ tanaman, $\mathrm{T}_{2}-40: 3$ tanaman dan $\mathrm{T}_{2}-45: 5$ tanaman. Seluruh tanaman generasi $\mathrm{T}_{1}$ tidak memiliki insert. Hasil ini menunjukkan bahwa gen Glu-1Dx5 sudah terintegrasi ke dalam genom tanaman padi kultivar Fatmawati dan diwariskan dari satu generasi ke generasi berikutnya.

Kata kunci: PCR, Padi Putatif Transgenik, Deteksi Transgen.

\section{PENDAHULUAN}

Nilai guna tepung gandum sangat beragam karena gandum memiliki gluten (salah satu seed storage protein, yang terdapat di endosperm biji) yang membuat adonan menjadi elastis, solid dan memiliki daya mengembang yang baik, sehingga sangat sesuai bila digunakan dalam beragam industri makanan, terutama dalam pembuatan roti (Shewry et al., 1995; Barro et al., 2003). Akan tetapi, sebaliknya adonan yang dibuat dari tepung beras memiliki kelemahan dalam hal elastisitas, kekuatan dan daya mengembangnya (viscoelasticity). Hal ini terjadi karena endosperm padi kekurangan protein yang mengendalikan karakter tersebut. Upaya peningkatan nilai guna tepung beras agar mendekati keunggulan tepung gandum, dapat dilakukan melalui peningkatan karakter kualitas biji padi dengan memodifikasi protein unik, terutama protein gluten sehingga mendekati gluten gandum.

Gluten terdiri dari dua tipe seed storage protein, yaitu glutenin dan gliadin. Glutenin terdiri dari dua subunit: High Molecular Weight (HMW) dan Low Molecular Weight (LMW). HMW glutenin subunit terdiri dari dua tipe, yaitu tipe $x$ dan $y$, gengen yang mengendalikan kedua subunit ini terpaut secara genetik dan terletak pada lengan kromosom pada group 1 genom A, B dan D (Payne et al., 1987). Alil-alil yang dikontrol oleh genom D memperlihatkan perannya yang besar dalam keragaman elastisitas dan kekuatan adonan tepung gandum beberapa kultivar dan galur-galur gandum yang berdekatan (near isogenic lines) (Shewry et al., 2003). Alil-alil ini terpisah sepanjang kurang lebih 25 kilo base pairs (kb) (Anderson et al., 2002). Beberapa gen/alil yang berperan dalam karakter enduse functionality ini, telah berhasil diisolasi dari gandum kultivar Cheyenne, suatu kultivar yang terkenal superior kualitas tepungnya sebagai bahan baku roti (Anderson et al., 1989; 2002). Salah satu alil yang teridentifikasi berkontribusi besar dalam mengendalikan elastisitas tepung gandum adalah Glu-D1-1b yang mengontrol subunit Dx5, sehingga disebut Glu-1Dx5. Gen ini memiliki peran besar dalam menentukan kualitas adonan tepung gandum (Payne et al., 1987; Shewry et al., 1995).

Mengingat akan perannya yang besar, gen Glu-1Dx5 yang dikontrol oleh promoter native-nya, telah ditransfer ke dalam genom tanaman padi melalui teknik transfer gen langsung ke dalam genom padi kultivar Fatmawati. Dengan bantuan PCR (polymerase chain reaction) beberapa galur $\mathrm{T}_{0}$ yang memiliki gen $G l u-1 D_{x}$, telah berhasil diseleksi (Carsono, 2007).

Padi kultivar Fatmawati dipilih sebagai target pada upaya transformasi genetik ini, karena hasil riset sebelumnya yang menunjukkan bahwa Fatmawati memilliki kemampuan menginduksi kalus yang berkualitas baik (Carsono \& Yoshida, 2006a), memiliki daya regenerasi yang tinggi (Carsono \& Yoshida, 2006b), serta tidak secara signifikan menginduksi variasi somaklonal (Carsono \& Yoshida, 2007).

Saat ini, transfer gen sudah banyak dilakukan pada beragam tanaman dan sudah dapat diterima sebagai komplemen pemuliaan tanaman konvensional. Melalui transfer gen, karakter unggul padi telah banyak dimuliakan contohnya: padi yang memiliki kandungan Fe tinggi (Goto et al., 1999), human lactoferrin /antimicrobial peptide (Nandi et al., 2002), rendah kandungan amylosa (Liu et al., 2005) and beta-carotene/' Golden Rice' (Datta et al., 2003).

Kultivar gandum yang ditransfer dengan gen Glu-1Dx5 (overexpression) memperlihatkan peningkatan kekuatan dan elastilitas adonan roti 
(Barro et al., 1997; Rooke et al., 1999, Blechl et al., 2007). Beberapa penelitian menyebutkan bahwa suatu gen asing yang sudah terintegrasi ke dalam genom inang, akan ditransfer ke keturunannya melalui proses seksual dan mengalami meiosis normal serta akan terekspresi dengan baik (Fearing et al., 1997; Scott et al., 1998). Duan et al. (1996) melaporkan bahwa gen proteinase inhibitor II yang diintroduksikan pada padi, dapat terekspresi dengan baik selama empat generasi. Akan tetapi, penelitian lain menyebutkan bahwa gen asing menjadi hilang melalui meiosis atau tidak berfungsi atau silenced pada generasi lanjut tanaman transgeniknya (Matzke \& Matzke 1995; Zhang et al., 1996).

Penelitian untuk mendeteksi keberadaan transgen pada suatu populasi tanaman yang telah mengalami proses penyerbukan sendiri menjadi suatu keharusan untuk menyeleksi tanamantanaman yang memiliki transgen. Untuk keperluan ini, teknik PCR (Polymerase Chain Reaction) merupakan salah satu teknik yang dapat digunakan.

Dua ratus empat puluh tanaman padi putative transgenik kultivar Fatmawati yang terdiri dari generasi $\mathrm{T}_{2}$ berjumlah 103 tanaman dan $\mathrm{T}_{3}$ berjumlah 137 tanaman, benih diambil dari sebagian hasil persilangan sendiri hasil penelitian Carsono (2007). Bahan-bahan tersebut merupakan koleksi Laboratorium Pemuliaan Tanaman Fakultas Pertanian Universitas Padjadjaran. Sampai saat ini, belum diketahui tanaman padi transgenik generasi $\mathrm{T}_{1}$ dan $\mathrm{T}_{2}$ tersebut di atas memiliki gen Glu-1Dx5. Oleh karena itu perlu diidentifikasi tanaman transgenik dari tanaman putative transgenik tersebut. Penelitian ini memiliki tujuan untuk memperoleh tanaman-tanaman yang memiliki insert (Glu-1Dx5).

\section{BAHAN DAN METODE PENELITIAN}

Penelitian dilakukan melalui eksperimen di rumah kaca tertutup dan percobaan di laboratorium. Benihbenih padi transgenik kultivar Fatmawati yang putative memiliki gen Glu-1Dx5, serta kultivar Fatmawati (sebagai kontrol) digunakan sebagai bahan utama penelitian. Sedangkan instrumen yang paling sering digunakan adalah PCR, electrophoresis, alat visualisasi DNA ( $U V$ transilluminator) dan alat pendukung untuk ekstraksi DNA seperti centrifuge, microwave, incubator shaker, dan microsentrifuge.

Bahan tanaman yang dianalisis molekuler terlebih dahulu ditanam di rumah kaca, dari bulan Februari 2009 sampai dengan Juli 2009. Penanaman padi dilakukan pada bak semen berukuran 5,30 $\mathrm{m} \mathrm{x}$ $1,17 \mathrm{~m}$ atau dengan luas $6,20 \mathrm{~m}^{2}$. Bak semen yang telah tersedia diisi tanah sawah asal Jatinangor yang dicampur dengan pupuk kandang (10 ton ha-1). Penanaman padi dilakukan pada dua bak semen, jarak tanam padi yang digunakan berukuran $20 \mathrm{~cm} \mathrm{x}$ $20 \mathrm{~cm}$, setiap lubang tanam padi terdiri dari satu bibit padi yang telah disemaikan.

Pemeliharaan tanaman meliputi penyiangan gulma, pengecekan air, dan pengendalian hama penyakit. Penyiangan dilakukan apabila ditemukan adanya gulma di sekitar lahan pertanaman. Penyiangan dilakukan manual dengan cara mencabut gulma dengan tangan. Penyiraman atau pengecekan air dilakukan dua atau tiga hari sekali, untuk menjaga agar tanaman padi tidak kekeringan.

Pada saat tanam, padi dipupuk dengan pupuk kandang sesuai rekomendasi. Sedangkan pada 14 hari setelah tanam (HST) dan $30 \mathrm{HST}$, pupuk yang diberikan yaitu pupuk $\mathrm{N}$ sebanyak $300 \mathrm{~kg} \mathrm{ha}^{-1}$, $\mathrm{P}_{2} \mathrm{O}_{5}$ sebanyak $100 \mathrm{~kg} \mathrm{ha}^{-1}$ dan $\mathrm{K}_{2} \mathrm{O}$ sebanyak $100 \mathrm{~kg}$ $\mathrm{ha}^{-1}$. Pengendalian gulma dilakukan secara manual. Pengendalaian hama dan penyakit dilakukan sesuai dengan gejala yang timbul di lapangan.

DNA genomik dari 241 tanaman (termasuk satu tanaman kontrol, nontransgenik kultivar asal, Fatmawati) diisolasi dari daun padi putative transgenik $\mathrm{T}_{2}$, dan $\mathrm{T}_{3}$. Ekstraksi DNA dilakukan dengan genomic DNA extraction kit (Fermentas), dengan mengikuti prosedur yang ada pada panduannya.

Konsentrasi DNA hasil ekstraksi kemudian dicek di agarose gel. Setelah diperoleh kepastian kualitas DNA yang baik, maka 1-0,5 $\mu$ l hasil ekstraksi DNA tersebut digunakan sebagai template untuk reaksi PCR. PCR dilakukan dengan menggunakan kondisi amplifikasi optimum yang sudah teruji (Carsono, 2007). Primer khusus yang didesign untuk mengamplifikasi coding region Glu$1 D \times 5$ sebesar 2,5 kb adalah: Forward 5'CCTCTTTGTGGCGGTAGTCGTC-3'; Reverse 5'AGTTCTATCACTGGCTGGCCGA-3'. Reaksi amplifikasi akan dilakukan dalam $40 \mu \mathrm{L}$ volume total yang mengandung $4 \mathrm{X}$ PCR bufer, $0.32 \mathrm{mM}$ dNTPs, 0.8 $\mathrm{mM}$ forward dan reverse primer, 1 Unit Go green Taq master mix (Promega) dan sekitar 20-100 ng genomic DNA sebagai template.

Amplifikasi fragmen dilakukan pada Thermocycler (Eppendorf) dengan profil satu siklus $93{ }^{\circ} \mathrm{C}$ selama 3 menit untuk denaturasi awal, 30 siklus: $93{ }^{\circ} \mathrm{C}$ selama 1 menit untuk denaturasi, 4 detik $58{ }^{\circ} \mathrm{C}$ untuk hibridisasi primer-DNA 
(annealing) dan $72{ }^{\circ} \mathrm{C}$ selama 2 menit 30 detik untuk pemanjangan (elongation), diikuti oleh 1 siklus $72{ }^{\circ} \mathrm{C}$ selama 5 menit untuk elongation akhir.

Produk amplifikasi akan dielektroforesis menggunakan 0,8 \% agarose gel pada 0.5 X TBE pada 100 volt selama 30 menit. Fragmen DNA divisualisasi dengan menggunakan UVtransilaminator yang dilengkapi dengan kamera. Kegiatan ini dilakukan di Lab. Analisis dan Bioteknologi Tanaman, Fakultas Pertanian Unpad, Jatinangor.

\section{HASIL DAN PEMBAHASAN}

Upaya mengidentifikasi keberadaan transgen pada suatu populasi tanaman putatif transgenik dilakukan dengan mendeteksi jaringan tanaman yang tertransformasi dengan sejumlah teknik diantaranya dengan teknik PCR. Pada penelitian ini, deteksi transgen Glu-1Dx5 dengan menggunakan teknik PCR dilakukan terhadap semua sampel tanaman padi transgenik kultivar Fatmawati generasi $\mathrm{T}_{2}$ sebanyak 105 tanaman dan $\mathrm{T}_{3}$ sebanyak 135 tanaman, serta satu tanaman kontrol, kultivar Fatmawati yaitu non transgenik dengan menggunakan primer spesifik untuk coding region dari gen Glu-1Dx5. Fragmen DNA yang dihasilkan dari amplifikasi tersebut mempunyai ukuran 2,5 kb. DNA genomik dari tanaman non transgenik dan plasmid pKDx5 (yang mengandung $8.4 \mathrm{~kb}$ genomic sequens dari Glu-1Dx5) digunakan berturut-turut sebagai kontrol negatif dan kontrol positif.

Hasil visualisasi produk PCR menunjukkan adanya beberapa sampel positif memiliki gen Glu$1 D_{x} 5$ dan ada juga beberapa sampel yang tidak memiliki insert (negative). Hasil deteksi analisis disajikan pada Gambar 1 dan Gambar 2. Pada hasil analisis produk PCR, beberapa tanaman memiliki intensitas pita/band yang jelas (tebal/tegas), sebaliknya ada pula yang rendah atau terlihat samar.

Intensitas pola pita yang tinggi terlihat tebal/tegas adalah pada nomor $1,8,9,10,11,12,13$, 17, 19, 20, 21, 22, 23 (Gambar 2), sedangkan pola pita yang rendah (tipis/samar) terlihat pada nomor 2, 3, 4, 5, 6, 7, 14, 15, 16 (Gambar 2). Ketidakstabilan pola pita yang dihasilkan dapat dipengaruhi oleh

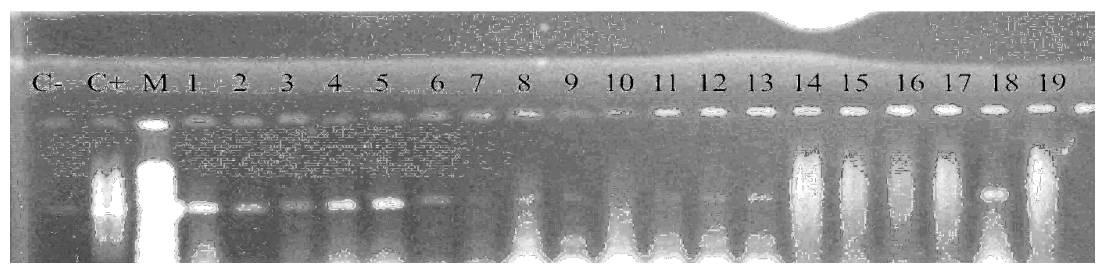

Gambar 1. Visualisasi produk PCR. Tanaman positif nomor 1, 2, 3, 4, 5, 6, 12, 13, dan 18.

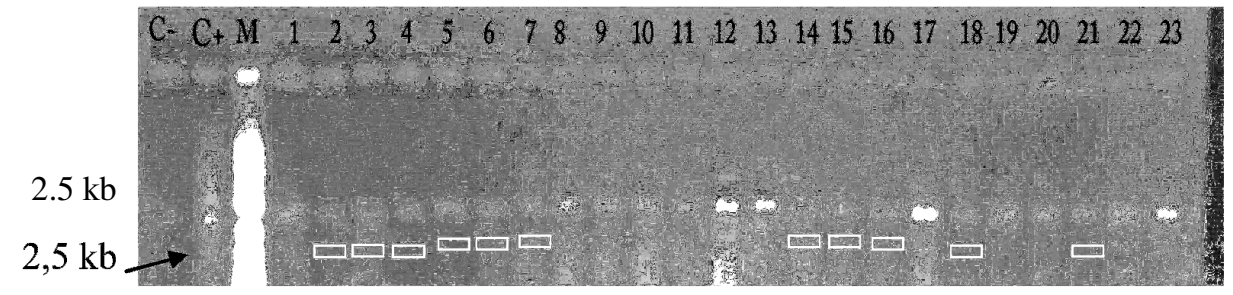

Gambar 2. Visualisasi produk PCR tanaman transgenik generasi T3-7. C-(kontrol negatif, template DNA berasal dari tanaman kultivar Fatmawati yang tidak ditransformasi), C+ (Kontrol positif, template DNA plasmid pK+Dx5), M (Marker 2 Log Ladder), 1-23 = nomor tanaman

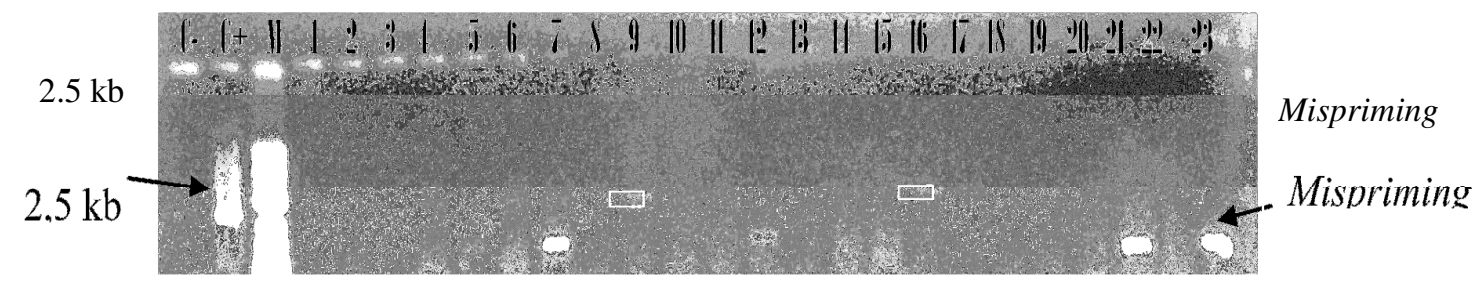

Gambar 3. Visualisasi produk PCR. C-: Kontrol negatif, template DNA berasal dari tanaman kultivar Fatmawati yang tidak ditransformasi;,C+: Kontrol positif, template DNA berasal dari plasmid pK+Dx5), M (Marker 2 Log Ladder), 1 - 23 = nomor tanaman. 
beberapa faktor diantaranya adalah konsentrasi DNA dan kualitas DNA hasil ekstraksi.

Kualitas DNA yang dihasilkan dari ekstraksi DNA tanaman berbeda-beda tergantung pada jenis tanamannya (Karakousis and Langride, 2003). Kualitas DNA yang kurang baik, pemurnian DNAnya tidak sempurna, kemungkinan masih mengandung polysacarida, senyawa fenolik atau kontaminan lainnya. Kontaminan dalam jumlah yang signifikan dapat mempengaruhi penempelan primer pada cetakan DNA. Kandungan fenol, tannin dan metabolit sekunder pada tumbuhan dapat mempengaruhi ekstraksi DNA dan akhirnya dapat mempengaruhi karakterisasi melalui PCR (Nkongolo et al., 1998).

Konsentrasi DNA yang diperlukan untuk PCR sangat sedikit (20 ng - $1 \mu \mathrm{g}$ ), sehingga jika konsentrasi DNA yang terlalu tinggi pada PCR dapat menyebabkan produk PCR yang berupa band atau fragmen DNA tidak teramplifikasi sehingga menghasilkan pola pita yang tidak konstan. Menurut Li et al., (2003), intensitas band atau fragmen pola pita dari produk PCR memiliki hubungan dengan copy number transgen yang dihasilkan. Intensitas band atau fragmen yang dihasilkan tinggi (tegas/tebal) dari hasil elektroforesis diduga bahwa copy number gennya lebih dari satu, tetapi bila band atau fragmen pola pita yang dihasilkan intensitasnya rendah (tipis/samar) maka copy number gennya diduga adalah satu.

Pada hasil analisis PCR (Gambar 3) terbentuk mispriming atau ukuran fragmen $(<1 \mathrm{~kb})$ lebih rendah dari fragmen yang diharapkan yaitu 2,5 $\mathrm{kb}$, hal ini dapat disebabkan oleh amplifikasi yang kurang effisien pada temperatur annealing sehingga menghasilkan produk yang tidak diharapkan.

Tabel 1 menunjukkan hasil deteksi insert pada populasi padi putatif transgenik generasi $\mathrm{T}_{2}$ dan T3. Dari Tabel 1 terlihat bahwa hanya galur $\mathrm{T}_{2-19}$ dan $\mathrm{T}_{2-20}$ yang memiliki persentase terbesar yang positif memiliki insert Glu-1Dx5 yaitu sebanyak $100 \%$ dan sebagian besar galur memiliki insert dengan persentase yang rendah. Hal ini terjadi karena tidak semua benih $\mathrm{T}_{2}$ dan $\mathrm{T}_{3}$ ini ditanam serta benih $\mathrm{T}_{3}$ yang ditanam ini tidak berasal dari benih $\mathrm{T}_{2}$ yang terseleksi (memiliki insert), sehingga masih terjadi proses segregasi gen. Sedangkan galur yang jauh dari proporsi yang diharapkan, bahkan untuk beberapa tanaman tidak memenuhi proporsi yang diharapkan karena tidak terdapat tanaman yang positif misalnya pada galur $\mathrm{T}_{2-12}$ dan $\mathrm{T}_{3-20}$. Kemungkinan terjadinya hal seperti ini diduga bahwa benih-benih tidak ditanam seluruhnya dan kemungkinan benih yang dilanjutkan ke generasi yang diuji merupakan benih dari tanaman yang tidak memiliki insert.

Dari hasil deteksi transgen ini, terlihat bahwa galur $\mathrm{T}_{2-19}$ dan $\mathrm{T}_{2-20}$ sudah tidak bersegregasi, sehingga diduga dalam konstitusi genetik yang homozigot. Akan tetapi karena jumlah tanaman yang diuji relatif kecil, maka kondisi ini masih perlu diuji pada generasi berikutnya.

Tabel 1. Hasil deteksi transgen Glu-1Dx5 tanaman padi transgenik kultivar Fatmawati $\mathrm{T}_{2}$ dan T3 dengan PCR

\begin{tabular}{cccrr}
\hline \multirow{2}{*}{ Generasi } & \multirow{2}{*}{ Galur } & Jumlah & \multicolumn{2}{c}{ Hasil Deteksi (dalam \%) } \\
\cline { 4 - 5 } & & Tanaman & \multicolumn{1}{c}{ Positif } & \multicolumn{1}{c}{ Negatif } \\
\hline \multirow{4}{*}{$\mathrm{T}_{\mathbf{2}}$} & 2 & 8 & $1(12,5 \%)$ & $7(87,5 \%)$ \\
& 7 & 40 & $11(27,5 \%)$ & $29(72,5 \%)$ \\
& 11 & 26 & $6(23,1 \%)$ & $20(76,9 \%)$ \\
& 12 & 16 & 0 & $16(100 \%)$ \\
& 19 & 5 & $5(100 \%)$ & 0 \\
& 20 & 4 & $4(100 \%)$ & 0 \\
$\mathrm{~T}_{3}$ & 25 & 4 & $2(37,9 \%)$ & $18(62,1 \%)$ \\
\hline & 7 & 35 & $26(74.3 \%)$ & $9(25,7 \%)$ \\
& 11 & 38 & $12(34,3 \%)$ & $23(65,7 \%)$ \\
& 12 & 15 & $3(20,0 \%)$ & $12(80,0 \%)$ \\
& 20 & 12 & 0 & $12(100 \%)$ \\
& 40 & 17 & $3(17,6 \%)$ & $14(82,4 \%)$ \\
& 45 & 20 & $5(25,0 \%)$ & $15(75,0 \%)$ \\
\hline
\end{tabular}

Pada Tabel 1 juga terlihat bahwa hanya generasi $\mathrm{T}_{2}$ galur 7 yang memiliki persentase paling mendekati proporsi yang diharapkan (3 transgenik berbanding 1 nontransgenik), akan tetapi sebagian besar galur tidak memperlihatkan proporsi ini.

Sangtong et al. (2002), mempelajari pewarisan gen Glu-1Dx5 pada beberapa generasi jagung transgenik. Terungkap bahwa beberapa kasus pewarisannya mengikuti hukum Mendel dan ada kasus yang pewarisannya tidak mengikuti hukum Mendel. Hasil penelitian ini pun terjadi hal yang sama. Hal ini karena tidak semua biji hasil penyerbukan sendiri generasi sebelumnya $\mathrm{T}_{1}$ (biji $\mathrm{T}_{2}$ ) dan $\mathrm{T}_{2}$ (biji $\mathrm{T}_{3}$ ) ditanam pada generasi berikutnya, sehingga rasionya tidak sesuai dengan rasio hokum Mendel.

\section{SIMPULAN}

Pada penelitian ini telah diperoleh tujuh puluh tujuh tanaman yang memiliki insert gen (Glu-1Dx5) dari sebelas galur yang positif. Galur-galur yang terseleksi memiliki transgen sebaiknya dilakukan pengujian 
lanjutan terutama pengujian fungsionalitas adonan tepung beras dan pengujian stabilitas ekspresi transgennya dari generasi ke generasi.

\section{UCAPAN TERIMA KASIH}

Penulis mengucapkan terima kasih kepada Program Insentif Riset Terapan tahun 2009 atas dukungan dana bagi terselenggaranya penelitian ini.

\section{PUSTAKA}

Anderson OD, Greene FC, Yip RE, Halford NG, Shewry PR and Malpica-Romero JM. 1989. Nucleotide sequences of the two highmolecular weight glutenin genes from the D-genome of hexaploid bread wheat, Triticum aestivum L., cv Cheyenne. Nucleic Acid Res 17: 461-462.

Anderson OD, Larka L, Christoffers MJ, McCue KF and Gustafson JP. 2002. Comparison of orthologous and paralogous DNA flanking the wheat high molecular weight glutenin genes: sequence conservation and divergence, transposon distribution, and matrix-attachment regions. Genome 45: 367-380.

Anderson OD, Rausch, C, Moullet O and Lagudah ES. 2003. The wheat D-genome HMWglutenin locus: BAC sequencing, gene distribution and retrotransposon clusters. Functional and Integrative Genomics 3: 5668.

Barro F, Rooke L, Bekes F, Gras P, Tatham A, Fido R, Lazzeri P, Shewry P, and Barcelo P. 1997. Transformation of wheat with high molecular weight subunit genes results in improved functional properties. Nature Biotechnol 15:1295-1299.

Barro F, Barcelo P, Lazzeri PA, Shewry PR, Ballestero J, and Martin, A. 2003. Functional properties of flours from fielmmd grown transgenic wheat lines expressing the HMW glutenin subunit $1 \mathrm{xA}$ and $1 \mathrm{Dx} 5$ genes. Mol Breed 12:223-229.

Blechl A, Lin J, Nguyen S, Chan R, Anderson OD and Dupont FM. 2007. Trangenic wheat with elevated levels of Dx5 and/or Dy10 high-molecular-weight subunits yield doughs with increased mixing strength and tolerance. J Cereal Sci. 45: 172-183.

Carsono N. 2007. The Establishment of in vitro
Culture and Genetic Transformation of the Wheat Glu-1Dx5 Gene to Rice Plants by Helios Gene Gun Bombardment. PhD Dissertation Thesis, Tokyo Univ of Agric \& Tech, Japan. Pp 110.

Carsono $\mathrm{N}$ and Yoshida T. 2006a. Identification of callus induction ability of 15 Indonesian rice genotypes. Plant Prod. Sci. 9:65-70.

Carsono N and Yoshida T. 2006b. Plant regeneration capacity of calluses derived from mature seed of five Indonesian rice genotypes. Plant Prod Sci. 9:71-77.

Carsono $\mathrm{N}$ and Yoshida T. 2007. Variation in spikelet-related traits of rice plants regenerated from mature seed derived callus culture. Plant Prod. Sci. 10:86-90.

Datta K, Baisakh N, Oliva N, Torizzo L, Tan J, Rai M, Abrigo E, Rehana S, Al-Babili S, Beyer P, Potrykus I and Datta SK. 2003. Bioengineered 'golden' indica rice cultivars with $B$-carotene metabolism in the endosperm with hygromycin and mannose selection systems. Plant Biotech J. 1: 81-90.

Duan X, Li X, Xue Q, Abo-El-Saad M, Xue D, and $\mathrm{Wu}$ R. 1996. Transgenic rice plants harbouring an introduced proteinase inhibitor II gene are insect resistant. Nature Biotechnol. 14: 494-498.

Fearing PL, Brown D, Vlachos D, Meghji M, Privalle L. 1997. Quantitative analysis of CryIA(b) protein expression in Bt maize plants, tissues, and silage and stability of expression over successive generations. Mol Breed. 3:169-176

Goto F, Yoshihara T, Shigemoto N, Toki S and Takaiwa F. 1999. Iron fortification of rice seed by the soybean ferritin gene. Nat Biotechnol. 17: 282-286.

Li F, Dey M, He C, Sangwan V, Wu X, and Wu R. 2003. Rapid-based determination of transgene copy number in rice. Plant Mol. Biol Reporter 21 : 73-80.

Liu QQ Yu HX, Chen XH, Cai XL, Tang SZ, Wang $\mathrm{ZY}$ and $\mathrm{Gu} \mathrm{MH}$. 2005. Field performance of transgenic indica hybrid rice with improved cooking and eating quality by downregulation of $W_{X}$ gene expression. Mol Breed. 16: 199-208.

Matzke M, and Matzke AJM. 1995. How and why do plants inactivate homologous (trans)genes?. Plant Physiol. 107:679-685. 
Nandi S, Suzuki YA, Huang J, Yalda D, Pham P, Wu L, Bartley G, Huang $\mathrm{N}$ and Lonnerdal B. 2002. Expression of human lactoferrin in transgenic rice grains for the application in infant formula. Plant Sci. 163: 713-722.

Nkongolo, K.K., K. Klimaszewska, and W. S. Gratton. 1998. DNA yields and optimization of RAPD patterns using spruce embryogenic lines, seedlings, and needles. Plant Mol. Biol. Reporter 16: 1-9.

Payne PI, Nightingale MA, Krattiger AF, and Holt LM. 1987. The relationship between HMW glutenin subunit composition and the breadmaking quality of British grown wheat varieties. J Sci Food Agric. 40:51-56.

Rooke L, Barro F, Tatham AS, Fido R, Steele S, Bekes F, Gras P, Martin A, Lazzeri PA, Shewry PR, and Barcelo P. 1999. Altered functional properties of tritordium by transformation with HMW glutenin subunit genes. Theor. Appl. Gene.t 99:851-858.

Sangtong V, Moran DL, Chikwamba R, Wang K, Woodman-Clikeman W, Long MJ, Lee M, Scott MP. 2002. Expression and inheritance of the wheat Glu-1Dx5 gene in transgenic maize. Theor. Appl. Genet. 105:937-945.

Scott A, Woodfield D, and White DWR.1998. Allelic composition and genetic background effects on transgene expression and inheritance in white clover. Mol. Breed. 4:479-490

Shewry PR, Tatham AS, Barro F, Barcelo P and Lazzeri P. 1995. Biotechnology of breadmaking: unraveling and manipulating the multi protein complex. Bio/technology 13:1185-1190.

Shewry PR, Halford NG, Tatham AS, Popineau Y, Lafiandra D and Belton PS. 2003. The high molecular weight subunits of wheat glutenin and their role in determining wheat processing properties. Adv. Food and Nutrition Res. 45:221-302.

Zhang S, Warkentin D, Sun B, Zhong H, and Sticklen M. 1996. Variation in the inheritance of expression among subclones for unselected (uidA) and selected (bar) transgenes in maize (Zea mays L.). Theor. Appl. Genet. 92:752-761. 